\title{
Broiler Meat Quality Evaluation Created in Simulated Conditions of Heat
}

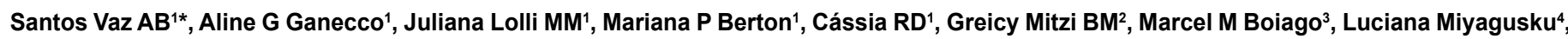
Hirasilva Borba ${ }^{1}$ and Pedro A de Souza ${ }^{1}$

${ }^{1}$ Faculty of Agrarian and Veterinary Sciences, University Estadual Paulista, Jaboticabal, São Paulo, Brazil

${ }^{2}$ Federal University of Alagoas, Arapiraca, Maceió, Brazil

${ }^{3}$ State University of Santa Catarina, Chapecó, Santa Catarina, Brazil

${ }^{4}$ Federal University of Mato Grosso do Sul, Campo Grande, Mato Grosso do Sul, Brazil

\begin{abstract}
The effect of different periods $(0,24,48$ and $72 \mathrm{~h}$ ) of condition heat on the physical and chemical qualities of broiler meat was evaluated. Five hundred Cobb $500^{\circledR}$ chicks were used, of which 100 were reared at a thermoneutral temperature, ideal for every rearing stage, constituting the control group. The other 400 animals were reared in a climate chamber at $32 \pm 2^{\circ} \mathrm{C}$, simulated conditions heat for birds. The physical and chemical qualities of the meat was evaluated at 21,35 , and 42 days. This experiment was carried out using a completely randomized design with a factorial of $2 \times 4$ (temperature and periods of conditions heat, respectively) and four replicates. The means were compared by Tukey's test at the $5 \%$ significance level. It was found that the heat affected the qualitative properties of the meat, particularly its lipid oxidation, water retention capacity, shear force, $r$ value, and $\mathrm{pH}$. Microbiological assessment was carried out on days 21,35, and 42 . The temperature treatments were not found to be associated with the occurrence of associated with the occurrence of any of the microbial species considered.
\end{abstract}

Keywords: High temperature; Physiological alterations; Qualitative properties

\section{Introduction}

Carcass quality is related to variations in conviction rate in the slaughterhouse, and primarily by factors such as age, sex, nutrition, handling, transportation, ambient temperature, time of fasting, and the method of harvesting birds on the farm [1]. Birds are homeothermic animals that have a thermoregulatory center located in their hypothalamus, which is constituted of neurons that are activated in response to temperature changes, triggering behavioral reactions and adaptive mechanisms for thermoregulation. This center is responsible for maintaining and controlling homeothermy through heat exchange with the environment [2]. When in high environmental temperatures, the optimum strategies adopted by the bird for heat dissipation are: increased respiratory rate hyperventilation and peripheral vasodilation, which do not promote evaporative heat loss [3].

Climatic aspects are the major limiting factor in the development of industrial production system in warm regions, because most modern commercial broiler strains were genetically improved for breeding in temperate countries. Therefore, heat stress is a particularly serious concern for the poultry industry in the tropics and during the summer in temperate countries, since it causes stunted growth, immunosuppression, and high mortality rates, resulting in significant economic losses in production [4].

The higher susceptibility of birds to heat stress is directly related to the relative humidity of the air and the environmental temperature because, when exposed to heat, compensatory physiological responses occur to enable a return to the thermal comfort zone [5].

The problems arising from increased susceptibility to heat stress causes changes in the chicken meat, seriously damaging the industrialization of meat products as well as causing increased rejection by the consumer due to the resulting physico chemical and organoleptic changes to the meat. An animal's defense against foreign agents such as viruses, bacteria, protozoa, and other parasites occurs due to the fundamental functioning of the immune system. The balance between immune system function and environmental challenges is a determining factor for animal health [6].
The main factors that negatively interfere with the immune system are stress caused by management, mycotoxins, and low levels of vitamins and minerals in the diet. Ensuring that these factors are controlled may improve animal health and productivity, as well as directly affect the cost of animal production. Over the past few years, the influence of stress on neuroimmune function has been widely studied, due to the notoriously damaging effects on individuals. Animals exposed to adverse situations suffer the effects of stress, including delays in growth, reproductive damage, and even death in animals grown for meat production [7]. It is also important to note that thermal stress, over a prolonged period, causes lesions to the mucosa of the gastrointestinal tract and hinders the absorption of nutrients $[8,9]$.

Salak-Johnson and McGlone [10] review studies of the effect of stress on immunity and particularly the suppression of the cellular and humoral immune responses. These authors concluded that stressful conditions trigger the release of glucocorticoids and this makes animals more susceptible to infectious diseases.

Thaxton and Siegel [11] and Miller and Quershi [12] showed that birds exposed to different types of environmental stress show reduced immune functions. When hens are exposed to temperatures varying from $32.2^{\circ} \mathrm{C}$ to $43^{\circ} \mathrm{C}$ for short periods, or cycles of constant high temperatures, the immune response is significantly reduced. Heckert et al. [13] showed that broilers subjected to overcrowding (20 birds/ $\mathrm{m}^{2}$ ), show reduced immune activity.

According to Fuller [14], any factor that causes an imbalance in

*Corresponding author: Santos Vaz $A B$, Faculty of Agrarian and Veterinary Sciences, University Estadual Paulista, Jaboticabal, São Paulo, Brazil, Tel: +5516-3301-4645; E-mail: alinebuda@zootecnista.com.br

Received October 18, 2016; Accepted November 04, 2016; Published November 11,2016

Citation: Santos Vaz AB, Ganecco AG, Lolli MMJ, Berton MP, Cássia RD, et al. (2016) Broiler Meat Quality Evaluation Created in Simulated Conditions of Heat. $J$ Food Process Technol 7: 634. doi: 10.4172/2157-7110.1000634

Copyright: ( 2016 Santos Vaz AB, et al. This is an open-access article distributed under the terms of the Creative Commons Attribution License, which permits unrestricted use, distribution, and reproduction in any medium, provided the original author and source are credited. 
intestinal microbiota may allow pathogenic microorganisms to invade and multiply; therefore, an imbalance of intestinal microbiota directly reflects the health of the host. According to Courrier [15], acute infections caused by Salmonella serotype Enteritidis usually occur in young birds or birds reared under stressful conditions.

The most significant pathogenic bacteria in aviculture are Salmonella spp.; Campylobacter jejuni, involved in gastroenteritis outbreaks; and Listeria monocytogenes, associated with meningitis and meningoencephalitis [16]. In addition to affecting animal productivity, these bacteria are hugely important to public health, since they are intimately related to infections from food. Bacteria such as Salmonella spp. are more frequent in human cases of food-borne illnesses from meat and chicken products. These bacteria are found in the intestinal tracts of humans and other animals and can multiply in culture and produce visible colonies at $37^{\circ} \mathrm{C}$ in $24 \mathrm{~h}$. The optimal $\mathrm{pH}$ for the development of Salmonella spp. is approximately neutral, with values above 9.0 and below 4.0 considered bactericidal Gast [17]

Another important group of microorganisms are Campylobacter spp., especially C. jejuni, which acts as a pathogenic agent or forms the normal microbiota of the gastrointestinal tract of animals such as cattle, birds, sheep, dogs, and cats [18]. Hence, meat is the greatest source of intestinal campylobacteriosis. L. monocytogenes is the only species of the genus Listeria that is pathogenic to humans. Listeriosis is the food-borne disease that causes the greatest number of deaths and hospitalizations (91\% of cases), particularly in pregnant women, newborns, and immunocompromised individuals [19].

Thus, conditions of heat is relevant in aviculture, since high temperatures may compromise bird immune systems resulting in increased proliferation of pathogenic bacteria and decreased populations of beneficial bacteria in the gastrointestinal tract. In this sense, stress may interfere with the behavior of intestinal microbiota, which protects the host against pathogens and opportunistic infections. Due to the issues described above, the aim of this work was to evaluate the impact of heat condition on the physical, chemical and microbiological qualities of chicken meat.

\section{Materials and Methods}

\section{Animals, initial management, and experimental conditions}

The work was submitted to the Ethics Committee on the Use of Animals of the Faculty of Agrarian and Veterinary Sciences, University Estadual Paulista and was approved under protocol number $4207 / 2010$. The experiment was conducted in climate chambers in the experimental aviary facility at Faculty of Agrarian and Veterinary Sciences, University Estadual Paulista - UNESP, Câmpus de Jaboticabal - Brazil.

For the experiment, 500 male Cobb strain 500 broilers were used. The animals received water and feed ad libitum during the 45 days of husbandry. The diets were formulated according to the ages of the birds and were based on their nutritional requirements Rostagno et al. [20] The animals were vaccinated against Gumboro disease (intermediate strain Lukert) for 7 and 19 day old birds, and against New castle disease (strain Ulster) for 12 and 24 day old birds.

Two climatic chambers were used to house the birds, with a density of 10 birds $/ \mathrm{m}^{2}$, distributed in boxes of $2.5 \times 1 \mathrm{~m}$ dimensions, containing 25 birds each. One hundred birds were kept in a chamber at a thermoneutral temperature, ideal for every stage of husbandry, according to the recommendations of Cobb. The other 400 birds were housed in another climatic chamber with heating and cooling systems, and were subjected to different periods of heat $(0 \mathrm{~h}, 24 \mathrm{~h}, 48 \mathrm{~h}$ and 72 $\mathrm{h}$ ), at which the camera's internal temperature rose to $32 \pm 2^{\circ} \mathrm{C}$. A 24 $\mathrm{h}$ light period was used throughout the experimental period in both chambers.

At 21 days of age the birds were subjected to different periods of conditions simulated heat. After maintaining condition heat for $72 \mathrm{~h}$ the heaters were turned off and the animals were kept in a thermoneutral environment until the next phase of simulated condition heat, at 35 and 42 days. After each condition heat simulated period, 12 birds from each chamber were slaughtered in the experimental abattoir in the aviary sector at FCAV / UNESP using conventional slaughtering procedures. The carcasses were then packed in plastic bags and placed in boxes with crushed ice until the time of analysis. The remaining birds stayed in their boxes until the next period of simulated conditions of heat.

\section{Evaluation of meat quality}

The carcasses were sent to the laboratory of Animal Products Technology at FCAV/UNESP, where physical and chemical analysis of the pectoralis major muscle was performed. The $\mathrm{pH}$ in the muscle was measures $24 \mathrm{~h}$ after slaughter using a Testo 205-digital $\mathrm{pH}$ meter, coupled to a Digimed glass probe.

The color was assessed in three parts of the muscle sample using a Minolta Chroma Meter CR-300 colorimeter, and the CIELab system to evaluate the $L^{*}$ (lightness) parameters, ranging from black (0) to white $(100), a^{*}$ (red content) ranging from green $(-60)$ to red $(60)$, and $b^{*}$ (yellow content), ranging from blue $(-60)$ to yellow (60). The water holding capacity (whc) was evaluated according to the methodology described by Hamm [21,22], by measurement of the water released when a $10 \mathrm{~kg}$ pressure is applied for five minutes to $0.50 \mathrm{~g}$ samples of muscle tissue. The percentage of water lost was calculated from the difference in sample weight before and after undergoing pressurization. To determine the weight loss by cooking (wlc). The samples were weighed and packed in plastic bags and cooked in a water bath at $85^{\circ} \mathrm{C}$ for $30 \mathrm{~min}$ until the internal temperature reached $75^{\circ} \mathrm{C}$. Next, the samples were removed from the bags, left at ambient temperature, and reweighed to calculate the weight loss [23].

The softness was evaluated from the shear strength of the samples after firing, taken perpendicular to the muscle fiber orientation, using Warner-Bratzler blade adapted with a Stable Micro Systems TA-XT2i texturometer, and the results were expressed as the maximum shear force in $\mathrm{kgf} / \mathrm{cm}^{2}$ [23]. The thiobarbituric acid reactive substances (tbars), resulting from lipid oxidation of the chicken meat samples, were determined according to the method described by Pikul et al. [24]. Triplicate samples, weighing around $10 \mathrm{~g}$ were homogenized with $50 \mathrm{~mL}$ of $7.5 \%$ trichloroacetic acid solution (tca) The supernatant was filtered and $4 \mathrm{~mL}$ aliquots of the filtrate were treated with $5 \mathrm{~mL}$ of thiobarbituric acid solution (tba), placed in boiling water, cooled, and analyzed with a spectrophotometer at $538 \mathrm{~nm}$. The results were expressed in milligrams of the tbars per $1 \mathrm{~kg}$ of sample. The value of $r$ was determined according to the methodology described by Honikel and Fischer [25]. This assessment was based on the extraction of nucleotides through homogenization with $1 \mathrm{M}$ perchloric acid using a ratio of, $1: 10 \mathrm{v} / \mathrm{m}$. After filtering, a $0.1 \mathrm{~mL}$ aliquot was diluted with $4.9 \mathrm{~mL}$ of $0.1 \mathrm{M}$ phosphate buffer at $\mathrm{pH} 7.0$ and was analyzed at $250 \mathrm{~nm}$ (inosine monophosphate) and $260 \mathrm{~nm}$ (adenosine triphosphate) in a spectrophotometer. The $\mathrm{r}$ value was determined from the ratio of the two absorbance wavelengths. 


\section{Preparation of swab dilutions}

Swab dilutions were prepared according to the methods of Apha (2001). From each sample, $1 \mathrm{~mL}$ of the swab transport solution was removed aseptically and placed into $9 \mathrm{~mL}$ of $0.1 \%$ sterilized peptone water, which was then homogenized in a Stomacher for one minute. An initial dilution of 10:1 was obtained, and decimal dilutions were prepared (up to 10:5) using the same dilutant.

\section{Detection of Campylobacter spp.}

To detect Campylobacter spp., the SimPlate method was used according the manufacturer specifications Biocontrol [26,27]. Initially, $1 \mathrm{~mL}$ of the sample, $9 \mathrm{~mL}$ sterile distilled water, $0.025 \mathrm{~mL}$ of rifampicin and $0.04 \mathrm{~mL}$ of Hemin were added to each tube containing the substrate to hydrate it. This mixture was then added to the center of the plates and distributed over all cavities using circular movements. The plates were incubated in an inverted position for $48 \mathrm{~h}$ at $42^{\circ} \mathrm{C}$ in the dark under microaerophilic conditions $\left(5 \% \mathrm{O}_{2}, 10 \% \mathrm{CO}_{2}\right.$, and $85 \%$ $\mathrm{N}_{2}$ ), in anaerobiosis jars. After incubation, the cavities were observed and those with color changes from yellow to red were considered presumptive positive samples. These plates that showed colored cavities were observed using a fluorescence camera under $365 \mathrm{~nm}$ UV light and the colored cavities that did not fluoresce were considered to be positive for Campylobacter. To confirm the positive results, the difference between the numbers of red and fluorescent cavities was estimated and the SimPlate conversion table was used to obtain the total Campylobacter count per plate.

\section{Detection of Escherichia coli}

For the Escherichia coli assay, the most probable number method described by Hunt and Rice [27] was used. A set of three tubes containing lauryl sulphate tryptose broth with 4-methylumbelliferylbeta-D-glucuronide (LST-MUG) by dilution were used, and $1 \mathrm{~mL}$ of the dilution was added to each tube of $10 \mathrm{~mL}$ LST-MUG. Next, the tubes were incubated at $35^{\circ} \mathrm{C} \pm 0.5^{\circ} \mathrm{C}$ for $24 \mathrm{~h}$ to observe the development and/or production of gas. In the samples with a positive result, i.e., those with growth and/or gas production, the tubes were observed under ultraviolet $(6 \mathrm{~W})$ and long-wave $(365 \mathrm{~nm}$ ) lamps. Those with blue fluorescence were confirmed as positive for $E$. coli. The result was based on the most probable number (MPN) table.

\section{Determination of the total enterobacteria}

For the total enterobacteria assays, the plate count method described by Kornacki and Johnson [28] was used. Each dilution (1 $\mathrm{mL}$ ) was inoculated onto empty sterile petri dishes and violet red bile glucose agar was added. After complete solidification of the medium, it was covered with an additional layer of the same medium. The plates were incubated in an inverted position at $35^{\circ} \mathrm{C} \pm 1^{\circ} \mathrm{C}$ for $24 \mathrm{~h}$. After the incubation period, the typical colonies of total enterobacteria were counted.

\section{Detection of lactic bacteria}

For the lactic bacteria assay, the plate count method of Hall and Yousef Hall and Yousef [29] was used. Each dilution $(1 \mathrm{~mL})$ was inoculated onto empty sterile petri dishes, and the Man, Rogosa and Sharpe culture media was subsequently added. The plates were incubated in an inverted position at $35^{\circ} \mathrm{C} \pm 1^{\circ} \mathrm{C}$ for $72 \mathrm{~h}$. After the incubation period, the plates with colonies were counted and those with at least five colonies present were selected for subsequent Gram staining and the catalase test. Isolation, selection, and identification of
Listeria monocytogenes and Salmonella spp. by real time polymerase chain reaction (RT-PCR).

To detect the presence of the pathogenic Salmonella spp. and $L$. monocytogenes, the real-time polymerase chain reaction was used (RT-PCR) Biocontrol [26], which currently is accepted for use by the Ministry of Agriculture, Livestock and Supply (MAPA) due to its specificity.

RT-PCR was performed using SYBR Green dye following the manufacturer's guidelines using Assurance GDS Rotor-Gene. If Salmonella spp. were confirmed, samples were subjected to a preenrichment, selective enrichment, differential plating, preliminary confirmation of typical colonies and a polyvalent somatic serological test.

\section{Pre-enrichment}

A portion of the $1 \mathrm{~mL}$ cloacal swab sample was homogenized in $9 \mathrm{~mL}$ of $0.1 \%$ buffered peptone water and incubated at $37^{\circ} \mathrm{C}$ for $18 \mathrm{~h}$.

\section{Selective enrichment}

The pre-enrichment tube was carefully shaken and $0.1 \mathrm{~mL}$ was transferred to $10 \mathrm{~mL}$ of Rappaport Vassiliadis broth and between $1 \mathrm{~mL}$ and $10 \mathrm{~mL}$ tetrathionate broth. The Rappaport Vassiliadis broth was incubated at $41.5^{\circ} \mathrm{C} \pm 1^{\circ} \mathrm{C}$ for $24 \mathrm{~h}$ and the tetrathionate broth at $37^{\circ} \mathrm{C}$ $\pm 1^{\circ} \mathrm{C}$ for $24 \mathrm{~h}$.

\section{Differential plating}

The selective enrichment tubes were shaken in a "vortex" agitator and a sample of the tetrathionate broth was streaked onto bismuth sulfite agar and xylose lysine deoxycholate agar. The same procedure was repeated using the Rappaport Vassiliadis broth. The plates were incubated in an inverted position at $35^{\circ} \mathrm{C}$ for $24 \mathrm{~h}$ to verify the development of typical colonies of Salmonella spp.

\section{Preliminary confirmation of typical colonies of Salmonella spp.}

When a suggestive colony was found, part of the cell mass was removed from the center of the typical colony using an inoculation needle and inoculated in inclined tubes containing iron lysine agar and triple sugar iron (TSI) Agar. Two typical colonies from each plate were selected, and inoculation was performed by stabbing and streaking on the slant, using the same loop to inoculate both tubes. The tubes were incubated at $35^{\circ} \mathrm{C} \pm 1^{\circ} \mathrm{C}$ for $24 \mathrm{~h}$ and the typical reaction for Salmonella spp. was observed.

\section{Polyvalent somatic serological test}

Two squares of approximately $2 \mathrm{~cm}^{2}$ were marked onto a glass slide, using a glass hydrophobic marker pen. A sample from the culture grown for $24 \mathrm{~h}$ in TSI was transferred with a loop to each of the squares, placing the culture sample in the upper part of each square. A drop of physiological saline solution was added to the lower part of one of the squares and the culture was thoroughly emulsified. A drop of polyvalent somatic serum anti-Salmonella spp. was added to the lower part of the other square. Holding the slide against a well-lit dark background, the slide was gently inclined and rotated in order to agitate the emulsion to observe the occurrence of agglutination in the square containing the serum. This result was compared with the result of the emulsion performed with the saline solution on the other square (the negative control), so that there was no confusion between cloudy appearance and an agglutination reaction. 


\section{Statistical analysis}

The experimental design was completely randomized in a factorial scheme of $2 \times 4$ (temperatures thermoneutral and simulated conditions of heat) duration of heat $(0,24,48$, and $72 \mathrm{~h})$ respectively, with four replications. The averages were compared by Tukey's test at a $5 \%$ significance level, using the SAS [30] statistical program.

\section{Results and Discussion}

The results obtained for the thiobarbituric acid reactive substances (tbars), water holding capacity (whc), shear force (sf) and weight loss by cooking (wlc) of the broiler meat at 21 days are shown in Table 1.

There was a significant correlation between the temperature (thermoneutral and heat) and the duration of heat with the tbars $(\mathrm{p}<0.01)$, whose breakdown is shown in Table 2. Through the breakdown of this correlation, it is found that the lipid oxidation degree of the meat from birds that were subjected to heat was higher. This is expected because a high body temperature can cause the release of steroids, initiating the peroxidation of membrane lipids, and thus oxidation of the meat from the birds that were subjected to heat at $32 \pm 2^{\circ} \mathrm{C}$ is increased. Heat stress can also cause disturbances in the balance between oxidant and antioxidant defense systems, causing lipid peroxidation and oxidative injury to proteins and DNA [31].

With regards to the results of the whe and sf, it is noteworthy that the duration of heat significantly alters these characteristics $(\mathrm{p}<0.01)$. The whc of meat was lower for birds that were subjected to $24 \mathrm{~h}$ of heat, as indicated by statistical difference $(p<0.01)$ with those that experienced $0 \mathrm{~h}$ of heat. However, the lower whc is consistent with the notion that the $\mathrm{pH}$ drops during maturation, for birds that were subjected to $24 \mathrm{~h}$ of heat, resulting in denaturation of myofibrillar proteins. Thus, this type of meat can cause irreparable disorder during industrialization providing income disabled during processing due to its difficulty in retaining water compared to regular meat. These results are similar to those reported by Fischer et al. [32] who found there was a lower whe in the breast meat of broilers reared under heat conditions.

Smoothness is a very important factor in the consumer's perception of meat quality. It is closely related to the amount of intramuscular water and, therefore, to the whc of the meat, so that the higher the water content in the muscle set, the greater the tenderness of the meat. According to the results obtained, it appears that the $72 \mathrm{~h}$ duration of heat caused more tenderness in the meat compared to other periods of 0-24 h, coinciding with a high who value.

Table 3 shows the results obtained for the analysis of lightness $\left(L^{*}\right)$, redness $\left(a^{*}\right)$, yellow intensity $\left(b^{*}\right), p H$, and $r$ value of broiler chicken meats at 21 days of age. It can be observed that there was only a significant correlation between the temperature (thermoneutral and heat) and the duration of heat with the $\mathrm{pH}$ variable $(\mathrm{p}<0.01)$ the breakdown of wich is shown in Table 4. Notably, the $\mathrm{pH}$ value of the meat at 21 days after heat for $24 \mathrm{~h}$ was significantly lower $(\mathrm{p}<0.05)$ than that for the control group. The low $\mathrm{pH}$ value in animals that were subjected to heat may be related to the acceleration of glycolysis reactions post mortem. Muscle tissues with $\mathrm{pH}$ values below 5.8 about 15 min after slaughter, when the carcass is still at near-physiologic temperatures, usually undergoes partial protein denaturation, impairing its functional properties by Tankson et al. [33].

The lightness $\left(\mathrm{l}^{*}\right)$, intensity of yellow $\left(\mathrm{b}^{*}\right)$, and redness $\left(\mathrm{a}^{*}\right)$ of broiler chicken meat at 21 days, showed no significant differences between the temperatures (thermoneutral and heat) tested and were not influenced by the period of exposure to high temperature $(p>0.05)$. Regarding the red content $\left(\mathrm{a}^{*}\right)$, a significant increase $(\mathrm{p}<0.05)$ in the chest of the birds that remained in a hot environment for $48-72 \mathrm{~h}$ compared to birds that were not exposed to heat is observed. Most authors found a higher red content in the muscles of birds reared in cold weather, reporting that the environmental temperature has a greater influence on the development of muscle fiber type.

The $r$ value differed $(\mathrm{p}<0.05)$ between temperature (thermoneutral and heat) and duration of the exposure. This value represents an indirect measure of the depletion of ATP in the muscle during the development of rigor mortis, with $r$ becoming greater as the ATP is

\begin{tabular}{|c|c|c|c|c|}
\hline & $\begin{array}{c}\text { Tbars } \\
\text { (mg TMP/Kg } \\
\text { am) }\end{array}$ & $\begin{array}{l}\text { whc } \\
(\%)\end{array}$ & $\begin{array}{c}\text { sf } \\
\left(\mathbf{k g f} / \mathrm{cm}^{2}\right)\end{array}$ & $\begin{array}{l}\text { wlc } \\
(\%)\end{array}$ \\
\hline \multicolumn{5}{|c|}{ Temperature ( $\mathrm{T})$} \\
\hline Thermoneutral & 0.021 & $70.90 \mathrm{~A}$ & $0.90 \mathrm{~A}$ & $30.44 \mathrm{~A}$ \\
\hline Heat & 0.266 & $69.86 \mathrm{~A}$ & $0.99 \mathrm{~A}$ & $31.12 \mathrm{~A}$ \\
\hline $\mathrm{F}$ test & $190.00^{* *}$ & $1.78^{\mathrm{NS}}$ & $0.88^{\mathrm{NS}}$ & $0.80^{\mathrm{NS}}$ \\
\hline \multicolumn{5}{|c|}{ Duration in hours of heat (D) } \\
\hline 0 & 0.077 & $73.71 \mathrm{~A}$ & $1.17 \mathrm{~A}$ & $30.97 \mathrm{~A}$ \\
\hline 24 & 0.109 & 68.37B & $1.02 \mathrm{~A}$ & $31.44 \mathrm{~A}$ \\
\hline 48 & 0.148 & $68.49 \mathrm{AB}$ & $0.86 \mathrm{AB}$ & $31.27 \mathrm{~A}$ \\
\hline 72 & 0.243 & $70.95 \mathrm{AB}$ & $0.74 \mathrm{~B}$ & $29.44 \mathrm{~A}$ \\
\hline $\mathrm{F}$ test & $34.04^{* *}$ & $10.62^{* *}$ & $3.38^{* *}$ & $1.45^{\mathrm{NS}}$ \\
\hline F Int. TxD & $30.39^{* *}$ & $0.72^{\mathrm{NS}}$ & $0.35^{\mathrm{NS}}$ & $0.18^{\mathrm{NS}}$ \\
\hline CV $(\%)$ & 11.37 & 3.77 & 16.71 & 8.55 \\
\hline
\end{tabular}

Averages in the same column followed by the same letter do not differ by Tukey's test $(5 \%) ;{ }^{* *}(p<0.01) ; C V=$ Coefficient of Variation; NS = Not Significant.

Table 1: Averages obtained for thiobarbituric acid reactive substances (tbars) water holding capacity (whc), shear force (sf), and weight loss by cooking (wlc) of broiler meat at 21 days of age.

\begin{tabular}{|c|c|c|c|c|}
\hline \multirow{2}{*}{ Temperature (T) } & \multicolumn{4}{|c|}{ Duration in hours of heat (D) - tbars (mg TMP/kg am) } \\
\cline { 2 - 5 } & $\mathbf{0 ~ h}$ & $\mathbf{2 4} \mathbf{~ h}$ & $\mathbf{4 8} \mathbf{~ h}$ & $\mathbf{7 2} \mathbf{~ h}$ \\
\hline Thermoneutral & $0.026 \mathrm{Ba}$ & $0.027 \mathrm{Ba}$ & $0.009 \mathrm{Aa}$ & $0.019 \mathrm{Ba}$ \\
\hline Heat & $0.085 \mathrm{Ac}$ & $0.538 \mathrm{Aa}$ & $0.163 \mathrm{Ab}$ & $0.277 \mathrm{Ab}$ \\
\hline
\end{tabular}

Averages in the same column followed by the same capital letter do not differ by Tukey's test $(5 \%)$; averages in the same row followed by the same lowercase letter do not differ by Tukey`s test (5\%).

Table 2: Breakdown of the interaction between temperature and duration (in hours) of heat for the means of the thiobarbituric acid reactive substances (tbars) of broiler meat at 21 days of age.

\begin{tabular}{|c|c|c|c|c|c|}
\hline & $I^{*}$ & $a^{*}$ & $\mathbf{b}^{*}$ & $\mathrm{pH}$ & $r$ value \\
\hline \multicolumn{6}{|c|}{ Temperature $(\mathrm{T})$} \\
\hline Thermoneutral & $50.19 \mathrm{~A}$ & $3.64 \mathrm{~A}$ & $2.76 \mathrm{~A}$ & 5.71 & $0.86 \mathrm{~B}$ \\
\hline Heat & $49.54 \mathrm{~A}$ & $3.39 \mathrm{~A}$ & $2.69 \mathrm{~A}$ & 5.58 & $0.96 \mathrm{~A}$ \\
\hline F-test & $0.56^{\mathrm{NS}}$ & $1.13^{\mathrm{NS}}$ & $0.07^{\mathrm{NS}}$ & $13.69^{* *}$ & $9.37^{* *}$ \\
\hline \multicolumn{6}{|c|}{ Duration in hours of heat (D) } \\
\hline 0 & $48.85 \mathrm{~A}$ & $2.91 \mathrm{~B}$ & $2.67 \mathrm{~A}$ & 5.79 & $0.73 B$ \\
\hline 24 & $50.26 \mathrm{~A}$ & $3.22 \mathrm{AB}$ & $2.87 \mathrm{~A}$ & 5.57 & $0.88 \mathrm{~A}$ \\
\hline 48 & $50.96 \mathrm{~A}$ & $4.01 \mathrm{~A}$ & $2.53 \mathrm{~A}$ & 5.62 & $0.95 \mathrm{~A}$ \\
\hline 72 & $49.44 \mathrm{~A}$ & $3.92 \mathrm{~A}$ & $2.82 \mathrm{~A}$ & 5.61 & $1.08 \mathrm{~A}$ \\
\hline $\mathrm{F}$ test & $1.10^{\mathrm{NS}}$ & $5.21^{* *}$ & $0.33^{\mathrm{NS}}$ & $7.00^{\star *}$ & $18.74^{* *}$ \\
\hline F Int. TxD & $0.17^{\mathrm{NS}}$ & $0.14^{\mathrm{NS}}$ & $0.25^{\mathrm{NS}}$ & $6.62^{* *}$ & $1.69^{\mathrm{NS}}$ \\
\hline CV (\%) & 6.08 & 18.22 & 10.45 & 2.17 & 12.35 \\
\hline
\end{tabular}

Averages in the same column followed by the same letter do not differ by Tukey's test $(5 \%) ;{ }^{* *}(p<0.01) ; C V=$ Coefficient of Variation; NS = Not Significant.

Table 3: Averages obtained for lightness $\left(\mathrm{I}^{\star}\right)$, redness $\left(\mathrm{a}^{*}\right)$, yellow intensity $\left(\mathrm{b}^{*}\right), \mathrm{pH}$ and $r$ value of broiler meat at 21 days of age. 


\begin{tabular}{|c|c|c|c|c|}
\hline \multirow{2}{*}{$\begin{array}{c}\text { Temperature } \\
\text { (T) }\end{array}$} & \multicolumn{4}{|c|}{ Duration in hours of heat (D) - pH } \\
\cline { 2 - 5 } Thermoneutral & 0 & 24 & 48 & 72 \\
\hline Heat & $5.58 \mathrm{Aa}$ & $5.99 \mathrm{Ab}$ & $5.63 \mathrm{Aa}$ & $5.63 \mathrm{Aa}$ \\
\hline
\end{tabular}

Averages in the same column followed by the same capital letter do not differ by Tukey's test $(5 \%)$; averages in the same row followed by the same lowercase letter do not differ by Tukey's test (5\%).

Table 4: Breakdown of the interaction between temperature and duration of heat (in hours) for the average $\mathrm{pH}$ of broiler meat at 21 days of age.

\begin{tabular}{|c|c|c|c|c|}
\hline & $\begin{array}{c}\text { tbars } \\
\text { (mg TMP/kg } \\
\text { am) }\end{array}$ & $\begin{array}{l}\text { whc } \\
(\%)\end{array}$ & $\begin{array}{c}\mathbf{s f} \\
\left(\mathbf{k g f} / \mathrm{cm}^{2}\right)\end{array}$ & $\begin{array}{l}\text { wlc } \\
(\%)\end{array}$ \\
\hline \multicolumn{5}{|c|}{ Temperature (T) } \\
\hline Thermoneutral & 0.008 & $73.18 \mathrm{~A}$ & $1.63 \mathrm{~A}$ & $27.94 \mathrm{~A}$ \\
\hline Heat & 0.065 & $70.07 \mathrm{~B}$ & $1.28 \mathrm{~B}$ & $27.87 \mathrm{~A}$ \\
\hline $\mathrm{F}$ test & $179.01^{* *}$ & $12.50^{* *}$ & $17.72^{* *}$ & $0.01^{\mathrm{NS}}$ \\
\hline \multicolumn{5}{|c|}{ Duration in hours of heat (D) } \\
\hline 0 & 0.021 & $72.08 \mathrm{~A}$ & $1.54 \mathrm{AB}$ & $27.65 \mathrm{~A}$ \\
\hline 24 & 0.031 & $71.83 \mathrm{~A}$ & $1.79 \mathrm{~A}$ & $27.98 \mathrm{~A}$ \\
\hline 48 & 0.041 & $71.47 \mathrm{~A}$ & $1.29 B C$ & $29.08 \mathrm{~A}$ \\
\hline 72 & 0.059 & $71.15 \mathrm{~A}$ & $1.19 \mathrm{C}$ & $26.89 \mathrm{~A}$ \\
\hline F test & $19.67^{\star *}$ & $0.23^{\mathrm{NS}}$ & $10.07^{\star *}$ & $1.76^{\mathrm{NS}}$ \\
\hline F Int. TxD & $19.37^{\star *}$ & $1.96^{\mathrm{NS}}$ & $0.42^{\mathrm{NS}}$ & $1.24^{\mathrm{NS}}$ \\
\hline CV $(\%)$ & 14.35 & 4.21 & 19.67 & 8.08 \\
\hline
\end{tabular}

Averages in the same column followed by the same letter do not differ by Tukey's test $(5 \%) ;{ }^{* *}(p<0.01) ; C V=$ Coefficient of Variation; NS = Not Significant.

Table 5: Averages obtained for thiobarbituric acid reactive substances (tbars) water holding capacity (whc), shear force (sf), and weight loss by cooking (wlc) of broiler meat at 35 days of age.

consumed. According to these results, it can be concluded that birds subjected to heat for 24,48 , and $72 \mathrm{~h}$ showed a faster decrease of ATP in the muscle, resulting in a higher $r$ value and accelerated rigor mortis. These results were similar to those reported by Marchi et al [34] who found higher $r$ values, for birds subjected to heat at $35^{\circ} \mathrm{C}$.

The tbars, whc, sf and wlc results for broiler meats at 35 days of age are presented in Table 5. It can be seen that there is a significant correlation between temperature (thermoneutral and heat) and the duration of the heat with the tbars $(p<0.01)$, whose breakdown is described in Table 6 . In analyzing the breakdown of this correlation, an increased lipidoxidation is observed in the meat of the birds that were subjected to heat. These data are consistent with those found by other authors, who report that heat leads to increased generation of free radicals, resulting in higher rates of lipid oxidation in the meat. Lin et al. [35] investigated the exposure of chickens to simulated conditions heat $\left(32^{\circ} \mathrm{C}\right.$ for $\left.6 \mathrm{~h}\right)$ and the results of this study suggest that elevated body temperature can induce metabolic disorders, causing oxidative stress and raising the tbars levels in the plasma and liver compared with the control chickens.

There was no correlation $(\mathrm{p}>0.05)$ between temperature (thermoneutral and heat) and the duration of heat for the whc, sf, and wlc at 35 days of age. There was a statistical difference $(\mathrm{p}<0.05)$ between the whc values obtained for birds at different temperatures (thermoneutral and heat).

The ability to retain water, one of the main contributors to the yield during product processing, was lower in birds stressed by heat, wich causes a reduced juiciness Fletcher [36] and lower product life Barbut [37]. The data obtained are consistent with those in the literature Woefel et al. [38] which identified a trend of reduced whe in meat originating from animals that were stressed before slaughter. The results show that the shear strength at the different temperatures (thermoneutral and heat) and the duration of heat influence the tenderness of the meat $(\mathrm{p}<0.05)$.

The softness increased in birds that were exposed to high temperatures for a heat period of $72 \mathrm{~h}$, differing significantly from that at $0-24 \mathrm{~h}$. The wlc of broiler meats at 35 days, showed no significant difference ( $p>0.05)$ for all temperatures (thermoneutral and heat) and was not affected by different periods of exposure to high temperature. The results of this study agree with the data obtained by Oba et al. [39], where the husbandry temperatures of 32 (hot), 26 (thermoneutral), and $18^{\circ} \mathrm{C}$ for animals at 47 days did not affect this characteristic.

Table 7 show no significant correlation $(p>0.05)$ between the temperature (thermoneutral and heat) and the duration of heat for the color $\left(1^{*}, a^{*}\right.$, and $\left.b^{*}\right), \mathrm{pH}$ and $\mathrm{r}$ value of chicken meat at 35 days.

The lightness $\left(1^{\star}\right)$ was influenced $(\mathrm{p}<0.05)$ by the temperature (thermoneutral and heat) with a lower $\mathrm{l}^{*}$ value being observed after heat. The length, 24 and $72 \mathrm{~h}$, for which the birds were subjected to high temperature, significantly affected the yellow intensity $\left(b^{*}\right)$ of the meat compared to the period of $0 \mathrm{~h}$ heat $(\mathrm{p}<0.05)$. As seen from Table 7 , there was no statistical difference $(\mathrm{p}>0.05)$ for the $\mathrm{pH}$ and $\mathrm{r}$ value, for the birds at different temperatures (thermoneutral and heat), in contrast to what was seen for the animal meats at 21 days. According to the data obtained, a lower incidence of pale breast meat was found in birds reared under stressful conditions. These results are similar to those previously described in the literature. Fischer et al. [15] found darker coloration reduced $l^{*}$ and less yellow reduced $b^{*}$ ) in the meat of birds subjected to heat stress at $35^{\circ} \mathrm{C}$. Bianchi et al. [40] when studying the influence of the seasons on the quality of broiler meat, observed that birds slaughtered during the summer also exhibited a pale chest which contradicts the results obtained in the present work.

\begin{tabular}{|c|c|c|c|c|}
\hline \multirow{2}{*}{ Temperature (T) } & \multicolumn{4}{|c|}{ Duration in hours of heat (D) - tbars (mg TMP/kg am) } \\
\cline { 2 - 5 } & 0 & 24 & 48 & 72 \\
\hline Thermoneutral & $0.004 \mathrm{Ba}$ & $0.013 \mathrm{Ba}$ & $0.007 \mathrm{Ba}$ & $0.007 \mathrm{Ba}$ \\
\hline Heat & $0.021 \mathrm{Ac}$ & $0.061 \mathrm{Ab}$ & $0.069 \mathrm{Ab}$ & $0.111 \mathrm{Aa}$ \\
\hline
\end{tabular}

Averages in the same column followed by the same capital letter do not differ by Tukey's test (5\%); averages in the same row followed by the same lowercase letter do not differ by Tukey's test (5\%).

Table 6: Breakdown of the interaction between temperature and duration of heat in hours for the average of the thiobarbituric acid reactive substances (tbars) of broiler meat at 35 days of age.

\begin{tabular}{|c|c|c|c|c|c|}
\hline \multicolumn{7}{|c|}{} & $\mathbf{I}^{*}$ & $\mathbf{a}^{*}$ & $\mathbf{b}^{*}$ & $\mathbf{p H}$ & r value \\
\hline \multicolumn{5}{|c|}{ Temperature (T) } \\
\hline Thermoneutral & $49.92 \mathrm{~A}$ & $3.23 \mathrm{~A}$ & $0.71 \mathrm{~A}$ & $5.53 \mathrm{~A}$ & $0.97 \mathrm{~A}$ \\
\hline Heat & $48.27 \mathrm{~B}$ & $3.48 \mathrm{~A}$ & $0.68 \mathrm{~A}$ & $5.59 \mathrm{~A}$ & $0.96 \mathrm{~A}$ \\
\hline F test & $7.73^{* *}$ & $0.91^{\mathrm{NS}}$ & $0.06^{\mathrm{NS}}$ & $1.69^{\mathrm{NS}}$ & $0.00^{\mathrm{NS}}$ \\
\hline \multicolumn{5}{|c|}{ Duration in hours of heat (D) } \\
\hline 0 & $49.17 \mathrm{~A}$ & $3.22 \mathrm{~A}$ & $1.38 \mathrm{~A}$ & $5.51 \mathrm{~A}$ & $1.05 \mathrm{~A}$ \\
\hline 24 & $48.98 \mathrm{~A}$ & $3.24 \mathrm{~A}$ & $0.35 \mathrm{~B}$ & $5.66 \mathrm{~A}$ & $0.99 \mathrm{~A}$ \\
\hline 48 & $49.05 \mathrm{~A}$ & $3.21 \mathrm{~A}$ & $0.77 \mathrm{AB}$ & $5.56 \mathrm{~A}$ & $0.94 \mathrm{~A}$ \\
\hline 72 & $49.18 \mathrm{~A}$ & $3.76 \mathrm{~A}$ & $0.29 \mathrm{~B}$ & $5.52 \mathrm{~A}$ & $0.88 \mathrm{~A}$ \\
\hline F test & $0.03^{\mathrm{NS}}$ & $1.10^{\mathrm{NS}}$ & $8.62^{* *}$ & $2.77^{\mathrm{NS}}$ & $1.73^{\mathrm{NS}}$ \\
\hline F Int. TxD & $0.39^{\mathrm{NS}}$ & $0.04^{\mathrm{NS}}$ & $0.16^{\mathrm{NS}}$ & $0.47^{\mathrm{NS}}$ & $1.72^{\mathrm{NS}}$ \\
\hline CV (\%) & 4.07 & 14.05 & 9.03 & 2.53 & 13.49 \\
\hline
\end{tabular}

Averages in the same column followed by the same letter do not differ by Tukey's test $(5 \%) ;{ }^{* *}(p<0.01)$; CV $=$ Coefficient of Variation; NS = Not Significant.

Table 7: Average obtained for lightness $\left(I^{*}\right)$, redness $\left(a^{*}\right)$, yellow intensity $\left(b^{*}\right), p H$ and $r$ value of broiler meat at 35 days of age. 
The results obtained for tbars, whc, sf, and wlc for broiler meat at 42 days of age are shown in Table 8 . There was a significant correlation $(p<0.01)$ between the temperature (thermoneutral and heat) and the duration of heat for tbars, the breakdown of wich is shown in Table 9. The breakdown of this correlation, shows higher lipid oxidation in meat from birds that were subjected to heat for periods of 24,48 , and $72 \mathrm{~h}$ of heat compared to that of $0 \mathrm{~h}$. These results suggest that the high temperature induced metabolic disorders involving oxidative stress, as was seen previously at 21 and 35 days.

There was no correlation $(p>0.05)$ between temperature (thermoneutral and heat) and the duration of heat for the whc, sf, and wlc at 42 days of age (Table 8 ). Of the evaluated parameters only the whe was not significantly different $(\mathrm{p}>0.05)$ at all temperatures (thermoneutral and heat) and durations of heat, contrary to what occurred at 21 and 35 days.

It is observed that the meat of the birds that remained in high temperatures for 24,48 , and $72 \mathrm{~h}$ was stiffer, than that at $0 \mathrm{~h}(\mathrm{p}<0.05)$, resulting in a decreased quality for this type of meat. However, higher rates of sf indicate that there was less post mortem proteolytic potential, leading to a decrease in softness.

The results indicate that the wlc in the breast muscle was affected $(p<0.05)$ by the duration of the heat. Greater wlc was observed in the breasts of birds kept at $32 \pm 2^{\circ} \mathrm{C}$ for $48 \mathrm{~h}$, averaging $30.64 \%$, than in the breasts of birds subjected to $32 \pm 2^{\circ} \mathrm{C}$ for $0 \mathrm{~h}$ with an average of $26.81 \%$. Some authors report that a faster rigor mortis leads to greater weight losses in cooking, but this hypothesis is not consistent with the results obtained in this work since the value of $r$ was not statistically different $(p>0.05)$ for the duration of heat (Table 10). Bressan and Beraquet [41] reported that the wlc in the chest muscles was influenced by the preslaughter environmental temperatures. The birds that were maintained at $30^{\circ} \mathrm{C}$ provided meat with wlc values $(28.7 \%)$ greater than birds reared at $17^{\circ} \mathrm{C}(27.2 \%)$.

There was no correlation $(p>0.05)$ between temperature (thermoneutral and heat) and the duration of heat for the color variables $\left(\mathrm{l}^{*}, \mathrm{a}^{*}\right.$, and $\left.\mathrm{b}^{*}\right), \mathrm{pH}$, and $\mathrm{r}$ at 42 days of age (Table 10). The results of color $\left(\mathrm{l}^{\star}, \mathrm{a}^{*}\right.$, and $\left.\mathrm{b}^{\star}\right)$ and $\mathrm{r}$, show that the temperature (thermoneutral and heat) and the duration of the heat does not significantly alter these features $(\mathrm{p}>0.05)$. A significant increase in the $\mathrm{pH}$ of meat from birds

\begin{tabular}{|c|c|c|c|c|}
\hline & \begin{tabular}{c|} 
tbars \\
(mg TMP/kg am)
\end{tabular} & $\begin{array}{l}\text { whc } \\
(\%)\end{array}$ & $\begin{array}{c}\mathbf{s f} \\
\left(\mathbf{k g f} / \mathrm{cm}^{2}\right)\end{array}$ & $\begin{array}{l}\text { wlc } \\
(\%)\end{array}$ \\
\hline \multicolumn{5}{|c|}{ Temperature (T) } \\
\hline Thermoneutral & 0.010 & $72.32 \mathrm{~A}$ & $2.15 B$ & $28.88 \mathrm{~A}$ \\
\hline Heat & 0.081 & $73.92 \mathrm{~A}$ & $2.74 \mathrm{~A}$ & $29.15 A$ \\
\hline F test & $145.94^{\star \star}$ & $1.67^{\mathrm{NS}}$ & $16.88^{* \star}$ & $0.11^{\mathrm{NS}}$ \\
\hline \multicolumn{5}{|c|}{ Duration in hours of heat (D) } \\
\hline 0 & 0.023 & $73.47 \mathrm{~A}$ & $1.87 \mathrm{~B}$ & 26.81B \\
\hline 24 & 0.047 & $72.69 \mathrm{~A}$ & $2.90 \mathrm{~A}$ & $29.60 A B$ \\
\hline 48 & 0.049 & $73.63 \mathrm{~A}$ & $2.49 \mathrm{~A}$ & $30.64 \mathrm{~A}$ \\
\hline 72 & 0.063 & $72.68 \mathrm{~A}$ & $2.52 \mathrm{~A}$ & $26.98 \mathrm{AB}$ \\
\hline $\mathrm{F}$ test & $8.26^{\star *}$ & $0.16^{\mathrm{NS}}$ & $8.94^{\star \star}$ & $3.87^{*}$ \\
\hline F Int. TxD & $5.19^{* \star}$ & $2.00^{\mathrm{NS}}$ & $2.54^{\mathrm{NS}}$ & $1.49^{\mathrm{NS}}$ \\
\hline CV (\%) & 10.52 & 5.80 & 15.05 & 9.80 \\
\hline
\end{tabular}

Averages in the same column followed by the same letter do not differ by Tukey's test $(5 \%) ;{ }^{*}(p<0.05) ;{ }^{* *}(p<0.01) ; \mathrm{CV}=$ coefficient of variation; NS = Not significant

Table 8: Averages obtained for thiobarbituric acid reactive substances (tbars) water holding capacity (whc), shear force (sf), and weight loss by cooking (wlc) of broiler meat at 42 days of age.

\begin{tabular}{|c|c|c|c|c|}
\hline \multirow{2}{*}{ Temperature (T) } & \multicolumn{4}{|c|}{ Duration in hours of heat (D) - tbars (mg TMP/Kg am) } \\
\cline { 2 - 5 } & 0 & 24 & 48 & 72 \\
\hline Thermoneutral & $0.015 \mathrm{Ba}$ & $0.005 \mathrm{Ba}$ & $0.011 \mathrm{Ba}$ & $0.009 \mathrm{Ba}$ \\
\hline Heat & $0.041 \mathrm{Ab}$ & $0.083 \mathrm{Aa}$ & $0.089 \mathrm{Aa}$ & $0.112 \mathrm{Aa}$ \\
\hline
\end{tabular}

Averages in the same column followed by the same capital letter do not differ by Tukey's test (5\%); averages in the same row followed by the same lowercase letter do not differ by Tukey's test (5\%).

Table 9: Breakdown of the interaction between temperature and duration (in hours) of heat for the average of the thiobarbituric acid reactive substances (tbars) of broiler meat at 42 days old.

\begin{tabular}{|c|c|c|c|c|c|}
\hline \multicolumn{7}{|c|}{} & $\mathbf{l}^{*}$ & $\mathbf{a}^{*}$ & $\mathbf{b}^{*}$ & $\mathbf{p H}$ & r value \\
\hline \multicolumn{5}{|c|}{ Temperature (T) } \\
\hline Thermoneutral & $49.48 \mathrm{~A}$ & $2.86 \mathrm{~A}$ & $0.59 \mathrm{~A}$ & $5.59 \mathrm{~A}$ & $0.91 \mathrm{~A}$ \\
\hline Heat & $48.84 \mathrm{~A}$ & $2.57 \mathrm{~A}$ & $0.89 \mathrm{~A}$ & $5.64 \mathrm{~A}$ & $0.94 \mathrm{~A}$ \\
\hline F test & $0.61^{\mathrm{NS}}$ & $2.19^{\mathrm{NS}}$ & $1.89^{\mathrm{NS}}$ & $0.72^{\mathrm{NS}}$ & $0.88^{\mathrm{NS}}$ \\
\hline 0 & Duration in hours of heat (D) \\
\hline 24 & $48.92 \mathrm{~A}$ & $2.62 \mathrm{~A}$ & $0.86 \mathrm{~A}$ & $5.45 \mathrm{~B}$ & $0.94 \mathrm{~A}$ \\
\hline 48 & $48.83 \mathrm{~A}$ & $2.55 \mathrm{~A}$ & $0.84 \mathrm{~A}$ & $5.48 \mathrm{~B}$ & $0.96 \mathrm{~A}$ \\
\hline 72 & $48.07 \mathrm{~A}$ & $3.12 \mathrm{~A}$ & $0.80 \mathrm{~A}$ & $5.52 \mathrm{~B}$ & $0.87 \mathrm{~A}$ \\
\hline F test & $49.83 \mathrm{~A}$ & $2.57 \mathrm{~A}$ & $0.76 \mathrm{~A}$ & $6.01 \mathrm{~A}$ & $0.94 \mathrm{~A}$ \\
\hline F Int. TxD & $1.08^{\mathrm{NS}}$ & $1.95^{\mathrm{NS}}$ & $0.61^{\mathrm{NS}}$ & $30.51^{* *}$ & $1.49^{\mathrm{NS}}$ \\
\hline CV (\%) & $0.14^{\mathrm{NS}}$ & $0.81^{\mathrm{NS}}$ & $2.64^{\mathrm{NS}}$ & $0.26^{\mathrm{NS}}$ & $0.18^{\mathrm{NS}}$ \\
\hline Av & 5.73 & 15.01 & 9.57 & 2.96 & 11.66 \\
\hline
\end{tabular}

Averages in the same column followed by the same letter do not differ by Tukey's test $(5 \%) ;{ }^{* *}(p<0.01)$; CV = Coefficient of Variation; NS = Not Significant.

Table 10: Averages obtained for lightness $\left(l^{*}\right)$, redness $\left(a^{*}\right)$, yellow intensity $\left(b^{*}\right)$, $\mathrm{pH}$, and $\mathrm{r}$ value of broiler meat at 42 days of age.

that remained in the heat for $72 \mathrm{~h}$, compared to periods of 0,24 , and $48 \mathrm{~h}(\mathrm{p}<0.05)$ was observed. The $\mathrm{pH}$ of the muscle has been associated with other meat quality attributes, including softness, whc, wlc, juiciness, and microbial stability. The final $\mathrm{pH}$ of the meat is intimately connected with the glycogen concentration in the muscle moments before slaughter, as this will significantly affect the $\mathrm{pH}$ reduction Roça [42]. According to the results, the highest $\mathrm{pH}$ value results from a depletion of glycogen in vivo, preventing reduction of the $\mathrm{pH}$ post mortem. However, it can be concluded that the rigor of the muscle was not sufficient for meat processing.

The results for Salmonella spp., L. monocytogenes, and Campylobacter spp. in the bird cloacal samples are shown in Table 1. Note that all results were negative during all experimental phases.

The results for the lactic bacteria, E. coli, and total enterobacteria counts on the cloacal swab samples are shown in Figures 1-3. The assay results of the 16 cloacal samples obtained using a swab from birds during their first few days of life were used to monitor the microbiological conditions that precede thermal heat in birds.

Note that there was no significant difference (Figures 1-3) in the incidence of lactic bacteria, E. coli, and total enterobacteria between the samples from animals that were grown at a thermoneutral temperature and those that were subjected to heat at $32^{\circ} \mathrm{C} \pm 2{ }^{\circ} \mathrm{C}$. In all samples, there was a significant increase in $\log \mathrm{UFC} / \mathrm{mL}$ or $\log \mathrm{NMP} / \mathrm{mL}$ over the 21 days; however, a correlation with acute heat could not be confirmed, since both the control samples and the samples with treatment showed the same profile.

\section{Conclusion}

Although determining the population of total enterobacteria was important, as it is a group of microorganisms frequently present in the gastrointestinal tract of birds. Lactic bacteria are associated with 
Citation: Santos Vaz AB, Ganecco AG, Lolli MMJ, Berton MP, Cássia RD, et al. (2016) Broiler Meat Quality Evaluation Created in Simulated Conditions of Heat. J Food Process Technol 7: 634. doi: 10.4172/2157-7110.1000634

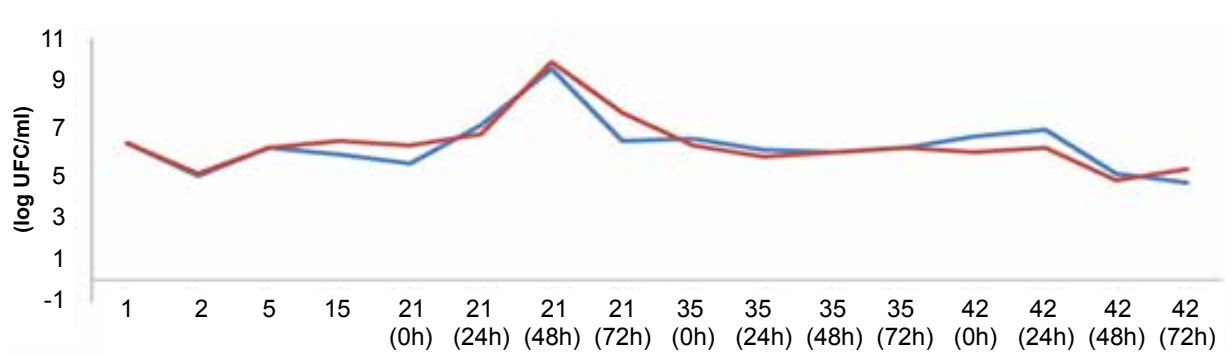

Idade das aves

- Amostra Controle Amostra Tratamento

Figure 1: Lactic bacteria counts in cloacal swab samples obtained from the broilers on the following experimental days: 1, 2, 5, 15, 21,35 , and 42 (at $0 \mathrm{~h}, 24 \mathrm{~h}, 48 \mathrm{~h}$, and $72 \mathrm{~h})$.

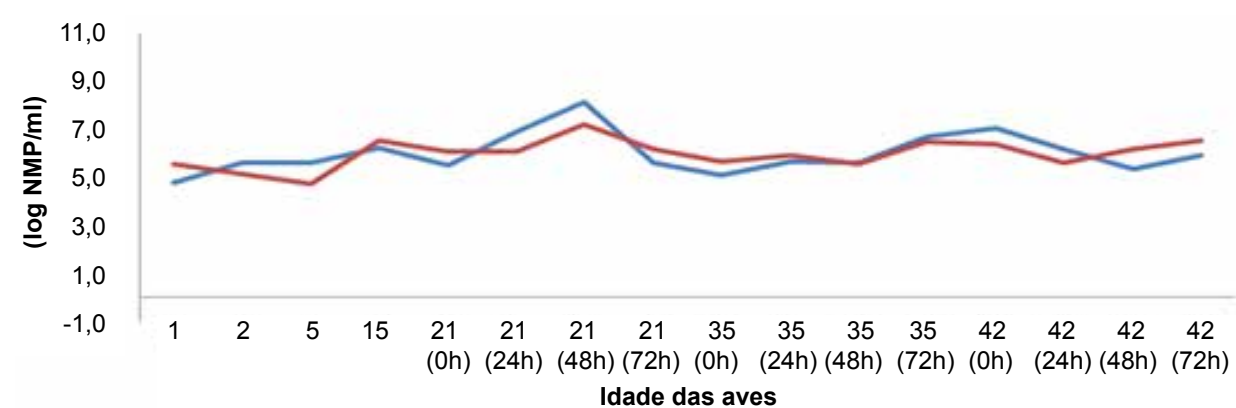

- Amostra Controle Amostra Tratamento

Figure 2: Results obtained for the Escherichia coli screening in cloacal swab samples from birds on the following experimental days: $1,2,5,15,21,35$, and 42 (at 0 h, $24 \mathrm{~h}, 48 \mathrm{~h}$, and $72 \mathrm{~h}$ ).

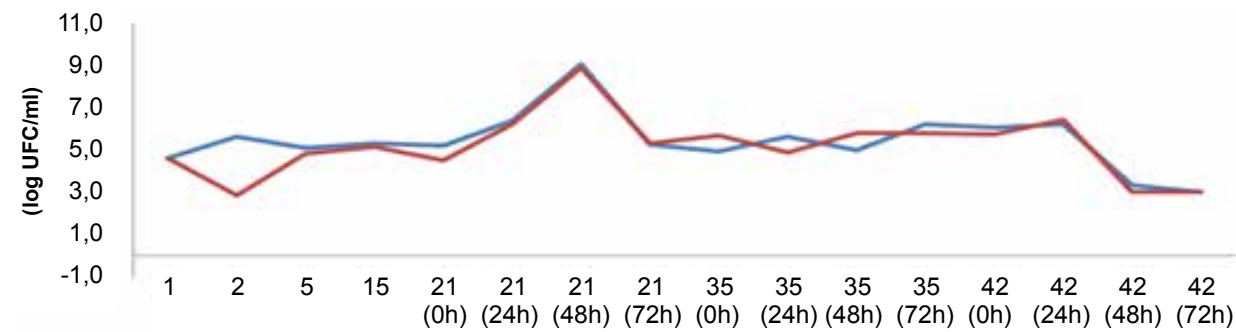

Idade das aves

- Amostra Controle Amostra Tratamento

Figure 3: Results obtained from the total Enterobacteriaceae screening in cloacal swab samples from the broilers on the following experimental days: $1,2,5,15,21$, 35 , and 42 (at $0 \mathrm{~h}, 24 \mathrm{~h}, 48 \mathrm{~h}$, and $72 \mathrm{~h}$ ).

protection against pathogenic microorganisms, and determining this population was important since in conditions of heat, the number of lactic bacteria may decrease, which contributes to an increase in pathogenic bacteria in the gastrointestinal flora. Thus, decreases in the zootechnic and physiological indices of animals are expected, but this was not observed in our study using heat.

In the available literature, we did not find articles assessing the relationship between heat and the incidence of lactic bacteria, Campylobacter spp., E. coli, total enterobacteria, and L. monocytogenes. However, some authors suggest that after heat, there may be a greater incidence of pathogenic microorganisms, since the increase in temperature decreases the immune response of birds, leading to a greater colonization of the intestine by pathogens in these animals.
Quinteiro-Filho et al. [43] verified that heat is capable of increasing Salmonella spp. colony forming units (UFC/g) in the spleen of animals and causes a decrease in weight gain and food consumption and an increase in mortality [44-48].

\section{References}

1. Mendes AA, Komiyama CM (2011) Management strategies aimed at broiler carcass and meat quality. Revista Brasileira de Zootecnia 40: 352-357.

2. Borges SA, Maiorka A, Da Silva AVF (2003) Fisiologia do estresse calórico e a utilização de eletrólitos em frangos de corte. Ciência Rural 33: 975-981.

3. Lavor CTB, Fernandes AAO, De Sousa FM (2008) Effect of thermal insulating materials in aviaries on broiler performance. Revista Ciência Agronômica 39: 308-316.

4. Renaudeau D, Collin A, Yahav S, De Basilio V, Gourdine JL (2012) Adaptation 
Citation: Santos Vaz AB, Ganecco AG, Lolli MMJ, Berton MP, Cássia RD, et al. (2016) Broiler Meat Quality Evaluation Created in Simulated Conditions of Heat. J Food Process Technol 7: 634. doi: 10.4172/2157-7110.1000634

to hot climate and strategies to alleviate heat stress in livestock production. Animal 6: 707-728

5. Caires CM, De Carvalho AP, Caires RM (2008) Nutrição de frangos de corte em clima quente. Revista Eletrônica Nutritime 5: 577-583.

6. Santin E (2012) Modulating the immune system of birds to increase productivity.

7. Moberg GP (2000) Biological response to stress: Implications for animal welfare. The biology of animal stress: basic principles and implications for animal welfare, Wallingford, England.

8. Kornacki, JL, Johnson JL (2001) Enterobacteriaceae, coliforms, and Escherichia coli as quality and safety indicators. Public Health Association, Washington.

9. Sifri M (2006) Informal nutrition symposium: dynamics of the digestive systemIntroduction. J App Poul Res 15: 122

10. Salak-Johnson JL, Mcglone JJ (2007) Making sense of apparently conflicting data: Stress and immunity in swine and cattle. J Anim Sci 85: 81-88.

11. Thaxton JP, Siegel HS (1982) Immuno-depression in young chickens by high environmental temperature. Poultry Sci 42: 202-220.

12. Miller L, Qureshi MA (1991) Introduction of heat shock proteins and phagocytic function of chicken macrophage following in vitro heat exposure. Vet Immunol Immuno 37: 34-42.

13. Heckert RA, Estevez I, Russek-Cohen E, Pettit-Riley R (2002) Effects of density and perch availability on the immune status of broilers. Poultry Sci 81: 451-457.

14. Fuller R (1989) Probiotics in man and animals: A review. J Appl Bacteriology 66: $365-378$.

15. Courrier DE (1991) Mycotoxicosis mechanisms of immunosuppression. Ve Immunol Immunop 30: 73-87.

16. Byrd JA, Anderson RC, Callaway TR, Moore RW, Knape KD, et al. (2003) Effect of experimental chlorate product administration in the drinking water on Salmonella typhimurium contamination of broilers. Poultry Sci 82: 1403-1406.

17. Gast RK (2003) Salmonella infections. Dis Poultry 11: 567-583.

18. Scarcelli E, Genovez ME, Cardoso MV, Souza MCAM, Grasso LMPS, et al (1998) Evaluation of the potential spread of Campylobacter spp. by different animal species. Arq Ins Biol 65: 55-61.

19. European Food Safety Authority (2006) The community summary report on trends and sources of zoonoses, zoonotic agents, antimicrobial resistance and foodborne outbreaks.

20. Rostagno HS, Albino LFT, Donizete JL, Gomes PC, De Oliveira RF, et al. (2005) Brazilian tables for poultry and swine: Food composition and nutritional requirements, Viçosa.

21. Hamm R (1960) Biochemistry of meat hydration. Adv Food Res 10: 335-443.

22. Cason JA, Lyon CE, Papa CM (1997) Effect of muscle opposition during rigor on development of broiler breast meat tenderness. Poultry Sci 76: 785-787.

23. Wheeler TL, Cundiff LV, Koch RM, Crouse JD (1996) Characterization of biological types of cattle (Cycle IV) carcass traits and longissimus palatability. J Animal Sci 74: 1023-1035.

24. Pikul J, Leszczynski DE, Kumerow FA (1989) Evaluation of three modified TBA methods for measuring lipid oxidation in chicken meat. J Agriculture and Food Chemistry 37: 1309-1313.

25. Honikel KO, Fischer C (1977) A rapid method for detection of PSE and DFD porcine muscles. J Food Science 42: 1633-1636.

26. Biocontrol (2010) Assurance GDS Genetic Detection System. USA
27. Hunt ME, Rice EW (2005) Microbiological examination. American Public Health Association, American Water Works Association \& Water Environment Federation, Washington DC 21: 949-958.

28. Kornacki JL, Johnson JL (2001) Enterobacteriaceae, coliforms, and Escherichia coli as quality and safety indicators. Public Health Association, Washington 4 69-82.

29. Hall ST, Yousef AE (2005) Tests for groups of microorganisms. Stand Met Examin Dairy Products. 17: 234-247.

30. SAS Institute (2002) SAS user's guide: statistics.

31. Droge W (2002) Free radicals in the physiological control of cell function. Physiological Reviews 82: 47-95

32. Fischer PC, Brossi C, Golineli BB, Castillo C (2005) Chicken breast quality subjected to acute heat stress. Piracicaba, São Paulo, Brazil.

33. Tankson JD, Vizzier-Thaxton Y, Thaxton JP, May JD, Cameron JA (2001) Stress and nutritional quality of broilers. Poultry Sci 80: 1384-1389.

34. Marchi DF, Oba A, Dos Santos GR, Soares AL, Shimokomaki M (2010) Evaluation of halothane as a stressor in chickens. Ciências Agrárias 31: 405 $-412$

35. Lin H, Decuypere E, Buyse J (2006) Acute heat stress induces oxidative stress in broiler chickens. Comparativ Biochem Physiol 144: 7-11.

36. Fletcher DL (2002) Poultry meat quality. World's Poultry Sci J 58: 131-145

37. Barbut S (1998) Estimating the magnitude of the PSE problem in poultry. $J$ Muscle Food 9: 35-49.

38. Woelfel RL, Owens CM, Hirschler EM, Martinez-Dawson R, Sams AR (2002) The characterization and incidence of pale, soft, and exudative broiler meat in a commercial processing plant. Poultry Sci 81: 579-584.

39. Oba A, De Souza PA, De Souza HBA, Leonel FR, Pelicano ERL, et al. (2007) Meat quality of broilers to diets supplemented with chromium, created in different ambient temperatures. Acta Scientiarum Animal Sci 29: 143-149.

40. Bianchi M, Petracci M, Sirri F, Folegatti E, Franchini A, et al. (2007) The influence of the season and market class of broiler chickens on breast meat quality traits. Poultry Sci 86: 959-963.

41. Bressan MC, Beraquet NJ (2002) Effect of pre-slaughter factors on the quality of chicken breast meat. Ciências Agrotecnicas 26: 1049-1059.

42. Roça RO (2002) Meat technology and related products. Faculdade de Ciências Agronômicas UNESP, Botucatu 45-51.

43. Quinteiro-Filho WM (2010) Heat stress impairs performance parameters, induces intestinal injury, and decreases macrophage activity in broiler chickens. Poultry Sci 89: 1905-1914.

44. Rostagno HS (2005) Brazilian tables for poultry and swine food composition and nutritional requirements. Publisher UFV, Viçosa MG.

45. Martindale RG (2005) Contemporary strategies for the prevention of stressrelated mucosal bleeding. Am J Hea Sys Phar 62: 511-517

46. Furlan RL, Macari M (2002) Termorregulação. Avian physiology applied to broilers, Jaboticabal.

47. NPAH (1995) Accreditation Standards for Monitoring and Diagnosis of avian Salmonella (S. enteritidis, S. gallinarum, S. pullorume, S. typhimurium) Laboratories. Ministry of Supply and Agricutura. Agriculture Defense Department, National Plan for Avian Health, Brazil.

48. American Public Health Association (2001) Committee on Microbiologica Examination of Foods. Comp met microbe examination of foods, American Public Health Association, Washington. 